\title{
落雷位置標定システムによる近畿地方の 雷観測結果
}

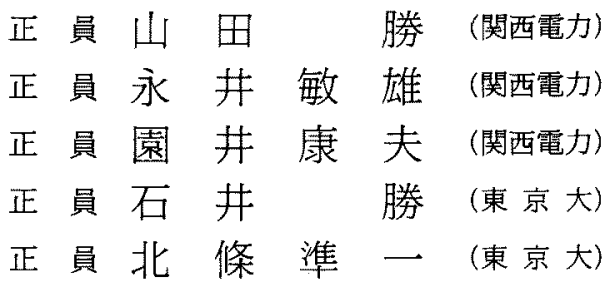

\section{Results of Lightning Observation in Kinki District by Direction Finder Network}

Masaru Yamada, Member, Tosio Nagai, Member, Yasuo Sonoi, Member (Kansai Electric Power Co., Inc.), Masaru Ishii, Member, Jun-Ichi Hojo, Member (University of Tokyo)

(1) As the LLP System calculated the current to be 2.3 times that of the true current, we adjusted it correctly.

(2) We graphed the cumulative frequency distributions curves of lightning current amplitudes for each season and polarity. The curves for negative polarity resemble a logarithmic normal distribution curve, but the curves for positive polarity don't. The current values of $50 \%$ are similar to the observed datas in Niigata.

(3) When we changed the criteria of electromagnetic field waveform of Cloud-to-Ground (CG) lightning in winter, we were able to improve the detection efficiency of the system from $40 \%$ to $70 \%$. We found that the electromagnetic field waveforms of lightning to high structures are different from the ones of CG lightning. And before we changed the criteria, the detection efficiency in summer lightning was more than $70 \%$.

(4) We made the detection efficiency curves for each distance and from the curves constructed lightning frequency level maps.

キーワード : 落雷位置標定システム, 冬季雷, 夏季雷, 雷撃電流累積頻度分布, 捕捉率, 落雷頻度マップ

\section{1.まえがき}

昭和 49 年ごろより，11月ごろからの寒波により発 生する冬季雷により日本海沿岸に位置する原子力発電 所からの $500 \mathrm{kV}$ 送電線などに 2 回線にまたがる多相 事故が夏季雷に比へ比較的多く発生した。この事故メ カニズム解明と事故防止対策を目指して，著者らは磁 界による落雷位置標定システム(1) (LLPシステムと 略記）をはじめとして各種の観測装置により精力的に 観測を実施してきた結果, 冬季雷の特徴と事故のメ力
ニズムが次第に明かになってきている(2)(3)。

ここでは，落雷位置標定システムによる近畿地方の 雷観測で現在までに得られた, ( i ) 雷揧電流波高値の 精度と累積頻度分布, (ii)システムの雷捕捉率とその 向上対策の結果，（iii）地域別の落雷頻度マップについ て，その概要を報告するものである。

\section{2. システムの概要}

本論文に用いた落雷位置標定システムは, 図 1 に示 すように近畿地方の北部に設置した日本海システムと 


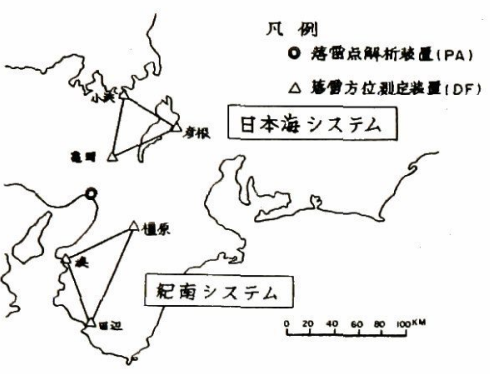

図 1 観測システムの配置

Fig. 1. Location of observation system.

呼んでいるシステムで, 落雷方位測定装置 (DF)の検 出感度は中感度（公称検出範囲 20〜200 km）に設定 している。このシステムの詳細については文献(1)を 参照されたい。なお，ここで分析したデー夕は稼働率 が高く，正および負の落雷が捕捉できる日本海システ ムの観測データを用いた。

小浜に設置した DF については, DF およびシステ ムの雷捕捉状況の検証のため, DF の直交ループアン テナ, 電界アンテナを利用して電磁界波形収集システ ム ${ }^{(4)}$ を設置している。

\section{3. 雷撃電流波高值の観測結果}

〈3・1〉雷撃電流の感度校正，㷌還雷撃電流によ り発生する電磁界変化波形の立上り部分の発生機構が 伝送線路モデルに従うとすると, 雷撃電流 $I$ と磁界 変化波形の波高值 $B$ との間に次の関係が得られる ${ }^{(5)}$ 。

$$
I=\frac{2 \pi c D}{\mu_{0} v} B
$$

ここに, $c:$ 光速, $D:$ 落雷点までの距離,

$\mu_{0}$ : 真空の透磁率, $v$ : 放電路上の電流進行

波速度 ( $c$ の $1 / 3$ を使用 ${ }^{(6)}$ )

LLP システムのマニュアル(7)では中感度の場合, 当初 ( 2 ) 式により雷電流を算出するよう推奨されてい たが，式の中の数值の根拠は明らかではない。現在は （3）式のとおり，（2)式の分母の 149 の代わりに218 が推奖値となっている。この改言された換算式は, 著 者らが行った平地に設置された DF 局の感度測定 ${ }^{(8)} の$ 結果とほほ一致した。

$$
I=S \cdot D / 149
$$

ここに, $S: \mathrm{DF}$ が出力する磁界信号強度に

比例した数值, $D(\mathrm{~km})$

現在は

$$
I=S \cdot D / 218
$$

改訂前の (2)式を観測結果に適用すると, 電流波高 値の累積頻度分布の 50 \% 值は他所で得られている観

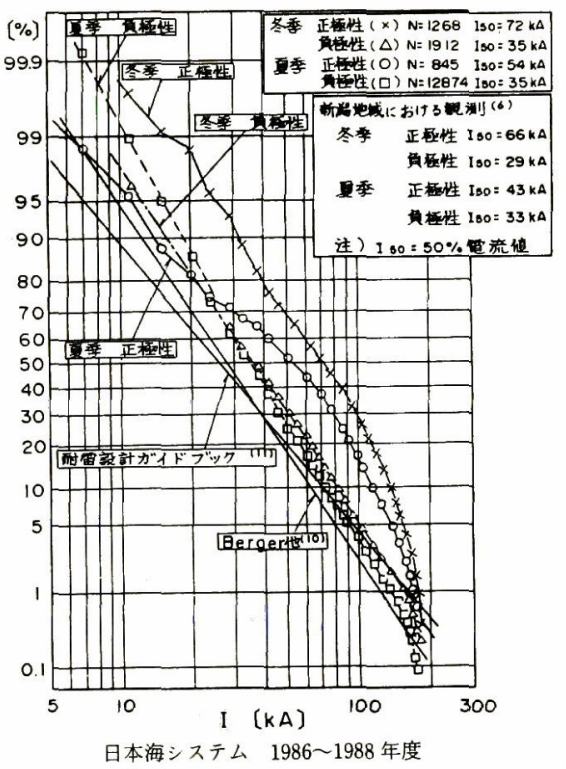

図 2 雷撃電流波高值の累積頻度分布曲線

Fig. 2. Cumulative frequency distributions of lightning current amplitudes.

測例に比べ，かなり大きくなった ${ }^{(9)}$ 。この疑問点を解 消するため，平面波とみなせるような数十 $\mathrm{km}$ 以上離 れた局からの長波帯の放送波（茨城県名崎の $40 \mathrm{kHz}$ 標準電波 JG 2 AS）を利用してDF の感度を校正し た(6)。この結果, 小浜, 亀岡, 彦根の各 DF で多少の ばらつきはあるものの, 改訂前の ( 2 ) 式を観測值にそ のまま適用して算出した電流值は，（1 ) 式で推定され る值の約 2.3 倍となっていたことが判明した。この原 因は当初の (2) 式の中の数值の誤りに加え, DFのア ンテナが鉄筋コンクリート構造物上に設置してあるこ とが，受信される信号強度に影響を及ぼしたためとみ られる。1989 年 4 月より各 DF を感度校正して観測 をしている。

〈3・2〉 雷撃電流波高値の分布一般に, LLP シ ステムで得られたデータをそのまま統計処理すると, DF の有限なダイナミックレンジのため真の分布形か らややひずんだ形状になる。すなわち，遠方の落雷の 中では小電流のものが検出されず，近傍では逆に大電 流のものが DF への入力が過大となり検出されなくな る。従ってここでは, $10 〜 75 \mathrm{~km}$ と 75〜200 km に区 分した距離別の電流分布を求め, 前者は小電流域が, 後者は大電流域の分布が正しいと仮定してひずみ補正 することにより，真に近い電流分布を推定できる ${ }^{(6)}$ 。 この方法により求めた分布が図 2 であり, 新潟地域に 


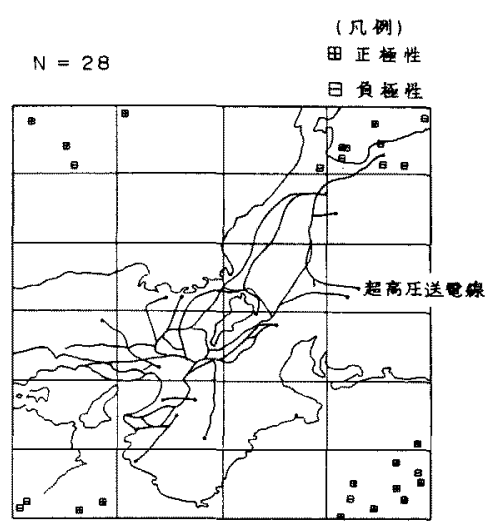

日本海システム 1985/11/25〜1989/3/31

図 3 大電流雷撃（300 kA 以上）の分布

Fig. 3. Distribution of lightning strokes with high current.

おける観湘結果 ${ }^{(6)}$ と類似の結果になっているが, Berger らの観溉 ${ }^{(10)}$ や耐雷設計ガイドブック(11) と比ベ ると, 夏季負極性の中央值は $30 \%$ 程度高くなってい る。分布形状怡負極性は夏季冬季ともに対数正規分布 といえるが，正極性は対数正規分布とは多少ひずんだ 形状になっている。また, 冬季, 正極性の大電流雷擊 の比率が高くなっている。

〈3・3〉 大電流雷撃の頻度 1985 年 11 月 27 日に 観測を開始してから 1989 年 3 月 31 日まで観測された 電流を補正して $300 \mathrm{kA}$ 以上の分布を示したのが図 3 である。DFのダイナミックレンジの影響で大電流雷 撃は遠方で 28 件観測されており最大值は $453 \mathrm{kA}$ ある。このうち, 冬季は 20 件 $(71 \%)$ で大電流雷撃の 比率が高くなっている。

\section{4. 落雷位置標定システムの捕捉率}

LLPシステムの捕捉率を左右する要素として， (i) 対地雷撃を識別するのに用いられる波形識別パラ メータの季節変化 ${ }^{(2)} に よ り$ 違うことによるもの， (ii) 雷撃電流の波高值が距離の関数で, かつ DF のダ イナミックレンジが有限であることにより捕捉率が距 離の関数となることによるもの ${ }^{(6)}$ (ここでは捕捉特性 と呼ぶ)，(iii) DF などの信号処理能力によるもの, (iv)電波伝搬する途中の山岳地形などに遮へいされ捕 捉できないことによるもの，などが考えられる。ここ では（i），（ii）の項目について検討した。

〈4・1〉 波形識別基準に関係する捕捉率ここの捕 捉率は，DFアンテナで受信する電磁界波形と DFが 雷と識別して出力するデー夕を比較分析することによ りつかむことができる。観測装置の詳細は文献 (4)を

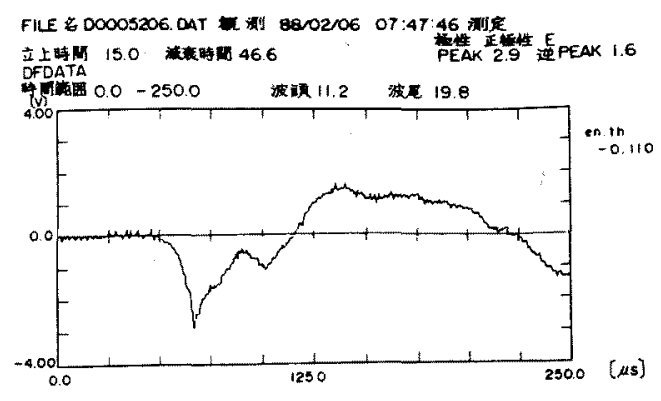

図 4 対地雷撃の電界波形例

Fig. 4. Example of Electric field waveform of cloud-to-ground lightning stroke.

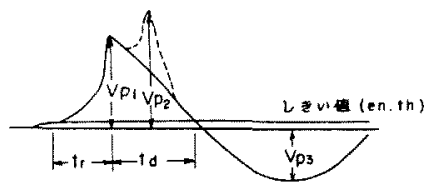

\begin{tabular}{|c|c|c|c|c|}
\hline \multirow{2}{*}{\multicolumn{2}{|c|}{ 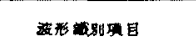 }} & \multirow{3}{*}{ 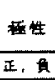 } & \multicolumn{2}{|c|}{ 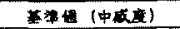 } \\
\hline & & & \multirow{2}{*}{ 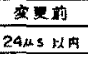 } & \multirow{2}{*}{ 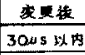 } \\
\hline \multirow{2}{*}{ 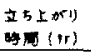 } & $(\mathrm{H})$ & & & \\
\hline & 111 & 正, & OOAs $1 \mathrm{~d}$ & $24, \mu \mathrm{s}$ 理内 \\
\hline \multicolumn{2}{|c|}{ 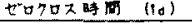 } & 正, & $12 \mu \mathrm{s} \cdot \mathrm{NR}$ & 原 \\
\hline \multicolumn{2}{|c|}{ 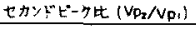 } & 正, & 1.25 以内 & 同 \\
\hline \multirow{2}{*}{\multicolumn{2}{|c|}{ 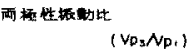 }} & 玨 & $0.50 \mathrm{~L} 2 \mathrm{H}$ & 0.70 纳内 \\
\hline & & 贫 & 0.75 次的 & 0.9014 \\
\hline
\end{tabular}

注) $(H)$ 中感度 DFで信号入力が約 60 nT 以下のとき(\$)

(L) 中感度 DFで信号入力が約 $60 \mathrm{nT}$ 以上のとき

図 5 落雷の波形識別項目と基準値 Fig. 5. Discriminative items and criteria about electromagnetic field waveform of lightning.

参照されたい。

対地雷擊の特徵は Weidman および Kriderによれ

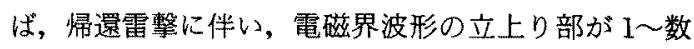
$\mu \mathrm{S} に わ た り ，$ 比皎的緩やかに上昇する部分（スロー フロント）とこの後, 急しゅんに立上ってピークに至 る部分 (ファーストトランジション) が認められると している ${ }^{(13)}$ 。この特徴を区分の基本として，まず得 られた電磁界波形データを大きく対地雷撃波形（波形 例を図 4 に示す) とそれ以外の波形（雲放電を含む） に区分する。更に冬季雷については後で詳述するよう に, 電磁界波形の形状加も大地に代表される比較的 フラットな地形への雷撃（平地雷撃と呼ふ）と送電鉄 塔に代表される高構造物への雷撃（高構造物雷撃と呼 ぶ）に分類して分析する必要があるが，本諭文では文 献(13)の特徵を備えた波形 (平地雷撃) のみを対地雷 撃として分析を行った。この点は今後の検討課題とし たい。この対地雷撃波形のうち，上記で区分されたデ 
ータについて図 5 に示す立上り時間，ゼロクロス時 間，セカンドピーク，融極性振動の各識別項目につい て検討した。その識別基準值を併せて図 5 に示す。

冬季, 夏季の電界波形の各識別項目を分析すると共 に，基本条件として DF が帰還雷撃と誌識して捕捉し ているか？ 次に, LLPシステムとしての捕捉率（3 DF 運用であり，1局が捕捉しなくても他の 2 局が捕 捉すればよい）を，更には DF が捕捉しない原因の波 形パラメータの分析を行い，総合的にまとめたのが表 1である。波形パラメータで一番影響を受けるのは冬 季, 夏季ともに両極性振動であり, 北條らの観測 ${ }^{(6)}$ と 同様の結果て，次にゼロクロス時間のパラメータであ ることがわかる。後者㹥雲放電を排除するうえでは有 効なパラメータである。日本海システムは識別基準を 1988 年 11 月に変更し，その前後で捕捉率がどのよう に変化したかも検討している。文献(14)においては, 基準值変更により刘地雷撃を平地雷撃と高構造物雷撃
に区分した場合，前者では LLPシステムの捕捉率が 約 $40 \%$ から $70 \%$ に向上することを報告したが，1日 のみのデータに基づいたこの結果には偏りがある可能 性もあるため, 気象状況の異なる日を含めて処理日数 を増やして検討した結果，表 1 に示すように同様の結 果となり, 平地雷揧については基準值変更により捕捉 率向上は可能であることが確実となった。

しかし，冬季雷による高構造物雷撃についてはほと んど標定していない年(14)。基準值変更後, $275 \mathrm{kV}$ 送 電線のトリップ事故を引起こした雷撃を好運にも標定 したときの電磁界波形を図 6 に示す。受信した第 1 波 形はゼロクロス時間が短いため対地雷撃による波形と は認識されず，第 2 波形が認識されて標定が行われた ものと考えられる。夏季雷についても，基準值変更前 の波形について分析を行った結果を表 1 に示す。これ によると, 日本における夏季雷は基準を変更しなくて も $74 \%$ の比較的高い捕捉率を有し, 新潟地方におけ

表 1 波形識別クライテリア変更前後における電界波形の波形識別パラメータ分析 と捕捉率の変化状況拉よび捕捉しない原因の分析

Table 1. Analyses of discriminative parameters of electric field waveform and change of detection effecienncy non-detective causes of winter and summer lightning.

\begin{tabular}{|c|c|c|c|c|c|c|c|c|c|c|c|c|}
\hline \multirow{3}{*}{$=$} & \multirow{3}{*}{ 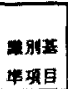 } & \multirow{3}{*}{ 精 } & \multirow{3}{*}{ 区 分 } & \multicolumn{6}{|c|}{ 条事孛一タ } & \multirow{2}{*}{\multicolumn{3}{|c|}{ 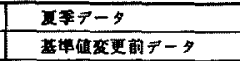 }} \\
\hline & & & & \multicolumn{3}{|c|}{ 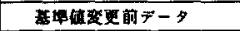 } & \multicolumn{3}{|c|}{ 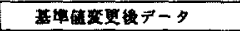 } & & & \\
\hline & & & & 昰4 & 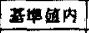 & 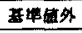 & 基童值 & 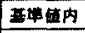 & 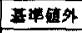 & 昰相 & 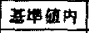 & 基策侮外 \\
\hline \multirow{4}{*}{ 果 } & \multirow{4}{*}{$\begin{array}{l}\text { 立5上 } \\
\text { がり } \\
\text { 形(tr) }\end{array}$} & \multirow{2}{*}{ 正 } & A $(\%)$ & \multirow{4}{*}{$\begin{array}{l}24 \not s \\
\text { 以内 }\end{array}$} & $55(96.5)$ & $2(3.5)$ & \multirow{4}{*}{$\begin{array}{l}3048 \\
\text { 2h内 }\end{array}$} & $117(98.3$ & $2(1.7)$ & \multirow{4}{*}{$\begin{array}{l}240 \mathrm{~s} \\
\text { D丙 }\end{array}$} & $18(100)$ & $0(0)$ \\
\hline & & & 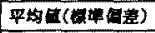 & & \multicolumn{2}{|c|}{$11.2 \mu s(4.76 \% s)$} & & \multicolumn{2}{|c|}{$13.1 \mu \mathrm{s}(5.32 \mu \mathrm{s})$} & & \multicolumn{2}{|c|}{$7.5,18(2.95,168)$} \\
\hline & & \multirow{2}{*}{ 自 } & 件 & & $21(100)$ & $0(0)$ & & $102(100)$ & 06 & & $109(100)$ & $0<$ \\
\hline & & & 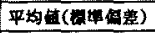 & & \multicolumn{2}{|c|}{$7.8 \mu \mathrm{s}(2.57 \mu \mathrm{s})$} & & \multicolumn{2}{|c|}{$9.5 \mu \mathrm{s}(3.64 \mu s)$} & & \multicolumn{2}{|c|}{$7.3 \mu \mathrm{s}(3.44 \mu \mathrm{s})$} \\
\hline \multirow{2}{*}{0} & \multirow{4}{*}{ 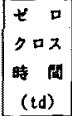 } & \multirow{2}{*}{ 正 } & 件 $(\%)$ & \multirow{4}{*}{$\begin{array}{l}12 \mu 8 \\
\text { 以上 }\end{array}$} & $50(87.7)$ & $7(12.3)$ & \multirow{4}{*}{$\begin{array}{l}12 \mu s \\
\text { 以上 }\end{array}$} & $101(84.9$ & $18(16.1)$ & & $17(94.4)$ & $1(5.6)$ \\
\hline & & & 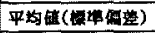 & & $33.5 \mu \mathrm{s}$ & $22.97 \mu 8)$ & & $37.9 \mu \mathrm{s}$ & $(40.4 \mu \mathrm{s})$ & & $31.8 \mu \mathrm{s}$ & $20.91 \mu \mathrm{s})$ \\
\hline$\therefore$ & & 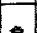 & 件 & & $17(81.0)$ & $4(19.0)$ & & $62(60.8)$ & $40(39.2)$ & 以上 & $109(100)$ & $0(0)$ \\
\hline$\overline{7}$ & & 是 & 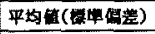 & & $32.4 \mathrm{ks}$ & $18.78 \mu \mathrm{s})$ & & $20.7 \mu \mathrm{sC}$ & $38.58 \mu \mathrm{s})$ & & $46.6 \mu \mathrm{s}$ & $13.32 \mu \mathrm{s})$ \\
\hline$\exists$ & tost & 正 & 件效 & 1.25 & 2 & 0 & 1.25 & 3 & 1 & 1.25 & 1 & 0 \\
\hline$x$ & $t=r$ & 角 & 件唯 & 以内 & 1 & 0 & DiA & 5 & 0 & 以内 & 1 & 3 \\
\hline t & 雨䟢性 & & 件 $(96)$ & 0.50 & \begin{tabular}{|l|}
$37(64.9)$ \\
\end{tabular} & $20(35.1)$ & 0.70 & 109691.6 & $10(8.4)$ & 0.50 & $14(77.8)$ & $4(27.2)$ \\
\hline 1 & 振動 & 非 & 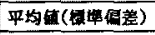 & D内 & 0.470 & .22) & 上内 & 0.420 & $.20)$ & 以内 & $0.36<0$ & .16) \\
\hline 3 & Yp3 & 争 & A $(\%)$ & 0.75 & $15(71.4)$ & $6(28.6)$ & 0.90 & $95(94.1)$ & $6(5.9)$ & 0.75 & $91(83.5)$ & $18(16.5)$ \\
\hline$\theta$ & $V_{01}$ & 員 & 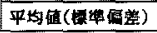 & 以内 & $0.58(0$ & .29) & QA & 0.640 & $22)$ & 以内 & $0.57<0$ & $.18)$ \\
\hline A & & 正! & Stet & & 57 & $(73.1 \%)$ & & 119 & $(63.8 X)$ & & 18 & $(14,2 x)$ \\
\hline 析 & felest & 負政 & 隹 & & 21 & $(37.98)$ & & 102 & $(46.2 x)$ & & 109 & $(85.8 *)$ \\
\hline & & Ât & $+(A)$ & & 78 & $(1004)$ & & 221 & $(100 x)$ & & 127 & $(100 \%)$ \\
\hline & $\infty 350 F$ & $\bar{y}^{*}-3$ & 青件数 $=(B)$ & & 46 & & & 158 & & & 88 & \\
\hline & $\bar{\varphi}$ 虻O & 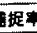 & $F=(B / A * 100 x)$ & & 59 & $0 x$ & & 71 & . $4 x$ & & 68 & $3 x$ \\
\hline (A) & のちちР & 聂定 & 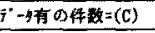 & & 30 & & & 158 & & & 94 & \\
\hline & $2 \approx \Delta 0$ & 6 & $=(c / 1 \times 100 x)$ & & 38 & $5 x$ & & 71 & . 48 & & 74 & . $0 x$ \\
\hline $\mathrm{D}$ & 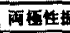 & & & & 154 & 6.8X) & & 136 & $0.6 \%)$ & & 153 & $8.5 \%$ \\
\hline 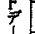 & 立与上小 & 10时 & & & 0 & & & 16 & $1.64)$ & & 0 & \\
\hline 5 & ぜロク口 & $x$ & & & $3(5$ & $9.4 x)$ & & 2063 & $1.74)$ & & 16 & $2.6 x)$ \\
\hline 架 & セカン & 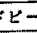 & & & 163 & $3.1 *)$ & & 11 & $1.8 x)$ & & 0 & \\
\hline 㟶 & 雨视性 & 政立 & 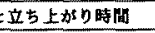 & & 216 & $8.3 x)$ & & 0 & & BPRSSP & 21 & $5.18)$ \\
\hline 筒 & 雨每生 & (t) & ビロクロス时凩 & & 113 & $3.15)$ & & 0 & & & 0 & \\
\hline 喼 & 不秎 & & & & $10(3$ & $1.2 x)$ & & 284 & $4.5 \mathrm{k})$ & & 216 & $3.8 x)$ \\
\hline 统 & 81 & & & & 3261 & $100 \%$ & & 631 & $100 \%$ & & 391 & $100 \%)$ \\
\hline 骠 & $\overline{7}-9$ & 又㽢基 & & $\begin{array}{l}1987.12 \\
1998: 1 \\
1988.2\end{array}$ & $\begin{array}{l}20 \sim 12.21 \\
21 \sim 1.28 \\
5 \sim 2.7\end{array}$ & & $\begin{array}{l}1989.11 \\
9989.12 \\
1989.1\end{array}$ & $\begin{array}{l}24 \sim 2612 \\
27 \sim 29\end{array}$ & $15 \sim 16$ & $\begin{array}{l}1988.6 \\
9988.8\end{array}$ & $25-6.9$ & \\
\hline
\end{tabular}




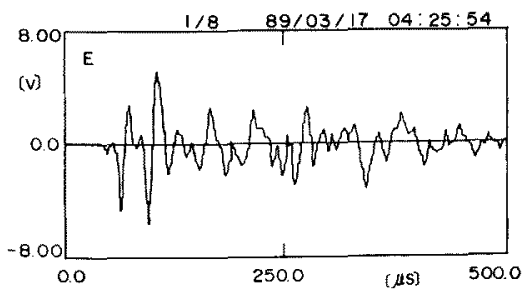

(a-1)霜界 第1波形

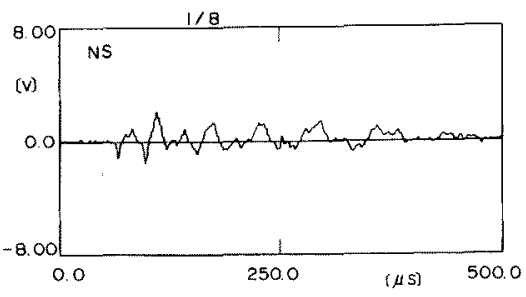

(b-1) NS 方向磁界 第 1 波形

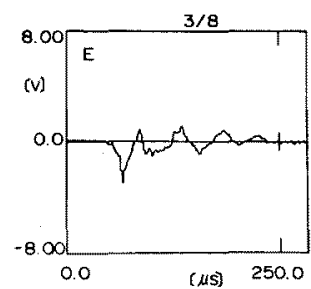

(a-2)第 2 波形（1番目のスタートより1s以内）

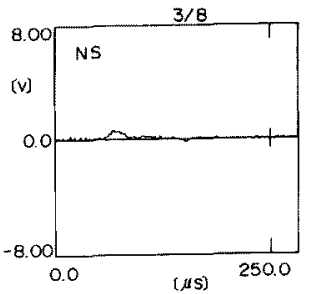

(b-2)第 2 波形（1番目のスタートより1

図 6 鉄塔雷撃時にDF が受信した電磁界波形（1989：03：17 04:25：55）

Fig. 6. Electromagnetic field waveforms of tower lightning by DF anntena.

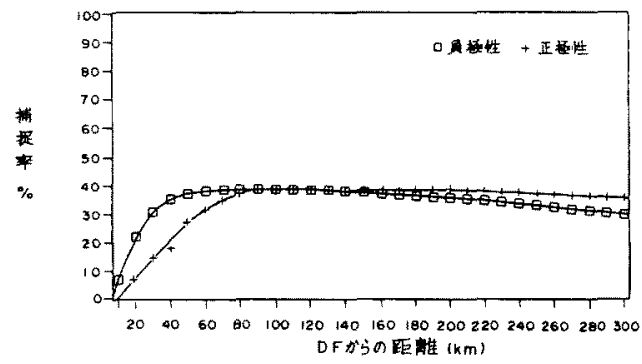

(a) 冬乎 (11 3月)

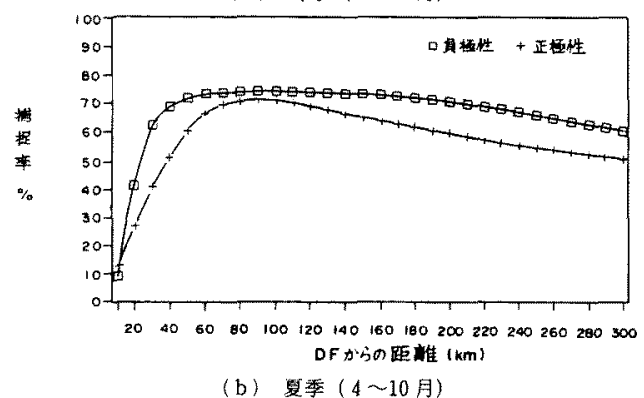

図 7 LLPシステムの捕捉率曲線 (1986〜1988データ)

Fig. 7. Detection efficiency curves of LLP system (datas from 1986 through 1988).

る北條らの観測( ${ }^{(6)}$ ，フロリダにおるる Peckham ら ${ }^{(15)}$ の観測結果に類似していることが判明した。また，冬 季雷による鉄塔雷撃のような複雑な波形はほとんど見 られなかった。

〈4・2〉 捕捉率の距離特性本章で記したように,
DFのダイナミックレンジの関係で捕捉率が距離によ り異なるため、この特性を求めるのに，まず各 $\mathrm{DF}$ 受 信信号強度分布を作成し, 受信可能な最大, 最小信号 強度を求める。この信号強度を基に各距離ごとに検出

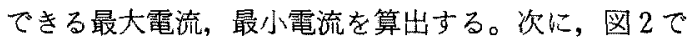
求めた雷撃電流累積頻度分布より検出できる最小電流 までの累積\%と最大電流までの累積\%を求め, その差 を求めると，任意の距離における捕捉率が求めら れる。

$\langle 4 \cdot 3\rangle$ 総合捕捉率 上記 $\langle 4 \cdot 1\rangle,\langle 4 \cdot 2\rangle$ 節で求め た 2 種類の捕捉率より，これらを考慮した総合捕捉率 が求められる。これを季節別, 極性別に求めグラフに したのが図 7 である（同図において先の波形識別基準 に関する捕捉率について夏季が $74 \%$ を，冬季が $38.5 \%$ を用いた)。これによれば，夏季は捕捉率が約 $70 \%$ と冬季の約 $40 \%$ に比べ高いことがわかる。この 結果は新潟地方に扝ける観測と䘞同様である。

\section{5. 落雷頻度マップ}

落雷頻度マップの作成は, 北緯 $33 \sim 37$ 度, 東経 134〜138度を各15分ずつのメッシュに区切って (IKL 相当) 1986 年度から 1988 年度に観測された落 雷位置データについて，そのメッシュ内の年・季あた りの頻度を求め, その数值を〈4・3〉節の総合捕捉率に より補正して求めた。捕捉率はメッシュの中心から最 も近距離にある DF は捕捉すると仮定し, LLS が標 


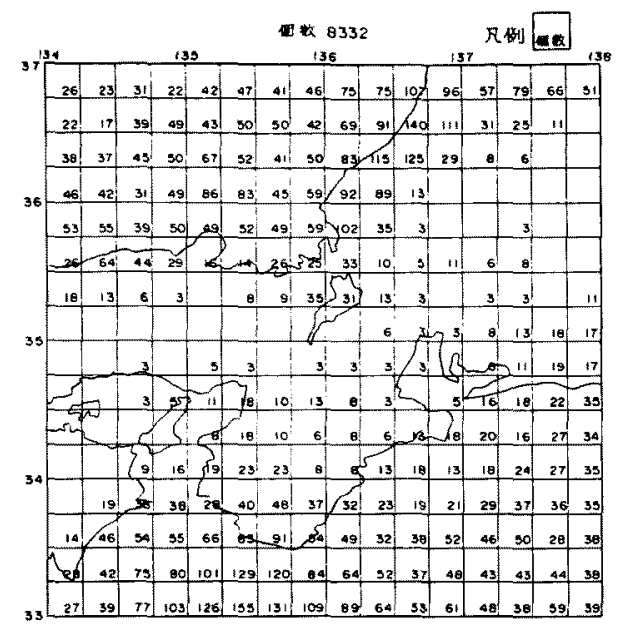

(a) 冬季 $(11 \sim 3$ 月) D落需頻度マッ

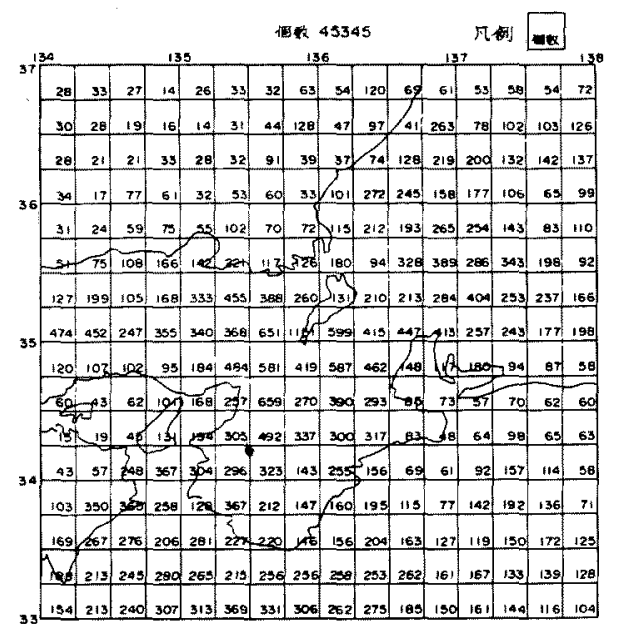

(b) 夏季 $(4 \sim 10$ 月) の落雷頻度マッガ

日本海システム 1986 ～1988 年度の年平均值

図 8 落雷頻度マップ，

Fig. 8. Lightning frequency level maps.

定するためにはメッシュの中心から 2 番目の距離にあ るDF が標定すればよいから，その距離における捕捉 率をそのメッシュに拉ける捕捉率として補正した。こ れらにより得られた季節別の正および負の落雷全数の 頻度マップを図 8 に示す。

\section{6. まとめ}

本諭文をまとめると，次のと敌りである。

（1）DFアンテナの感度校正を行った結果，距界 による落雷位置標定システムのマニュアルに従って， 当初算出していた雷撃電流値は妥当な推定値の約 2.3 倍となっていたことが判明した。原因はマニュアルの
数值の誤りに加え，各 DF サイトが鉄筋コンクリート 構造物の上であるなどの，サイト悪条件によるものと 推定される。

（2）雷慗電流波高值の累積頻度分布を季節別，極 性別に作成した。負極性は夏季冬季とも対数正規分布 をなすが，正極はその分布形状を示さない。電流值の 中央値は新潟地方の観測と類似する。

(3) LLPシステムの捕捉率について, 波形パラ メータによるものとDFのダイナミックレンジに伴う 距雄特性について検討した。前者は，冬季の場合，平 地雷撃は波形識別基準值を変更することにより, 捕捉 率向上は可能である。鉄塔などの高構造物雷撃につい ては,その電磁界波形の形状が平地雷撃とは違うこと が明確になった。また，夏季の場合，基準值変更前で も捕捉率は $70 \%$ 以上あることが判明した。

更に，上記の波形パラメータによる捕捉率と捕捉率 が距雒特性をもつことの両方を考慮した総合捕捉率曲 線を作成した。

（4）上記の総合捕捉率曲線を基に真に近い季節別 の雷摮頻度マップを作成した。

今回の分析により近畿地方における雷擊電流の波高 值の頻度分布, LLP システムの捕捉率, 落雷頻度マ ップを明らかにした。このなかで夏季の捕捉率は高い ので問題ないが，冬季は我々が最も重要視する鉄塔雷 撃をほとんど標定せず，この現象の解明と落雷頻度マ ップの送電線雷事故率検討など, 設計面への適用が今 後の課題である。

(平成 2 年 5 月 25 日受付，同 2 年 8 月 30 日再受付)

$$
\text { 文献 }
$$

(1) Binford, et al.: "Wideband Magnetic Direction Finder Networks for Locating Cloud -to-Ground Lightning", 1983 Int. Aerospace And Ground Conf, on Lightning and Static Electricity, Fort Worth, 50 (1983)

（2）水野，他：「500 kV 送電線 2 回線事故様相の考察」，電氮学 会放電・高電医合同研資, ED-88-87；HV-88-48（憁 63）

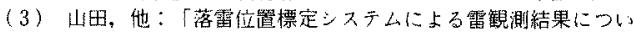
て (その2)」, 同上. $\mathrm{ED}-89-94: \mathrm{HV}-89-37$ (平元)

（4）水野，他：个落雷位置標定システムの力向探知アンデに上 る電磁舅波形観測々識別」同上, $\mathrm{ED}-88-85 ; \mathrm{HV}-88-46$ (昭63)

(5) Y.T. Lin, et al. : "Lightning Return Stroke Models", J. Geophys. Reas., 85 (1980)

（6）北條，他：「落雷に伴う電距界帘化波形の特性と評䛧法了, 電学論 B，108，165 (昭 63-4)

(7) LIGHTNING LOCATION AND PROTECTION, INC.: Operating Manual Lightning Position Analyzer Model PA80-02 Oct. 241984

(8) M. Ishii \& J. Hojo: "Calibration of Wideband Magnetic Field Mesuring System for Observation of Lightning". Tians. IEE of Japan. 108. 121 (1988)

（9）水野，他：【落雷位置標定システムに上る雷葓測結果につい

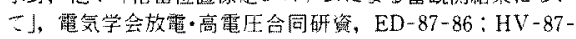
33 (昭 62) 
(10) K. Berger, et al. : "Parameters of Lightning Flashes", Electra. No. 41.23 (1975)

（11）耐雷設計基準委員会：「送電線耐雷設計ガイドブック」, 電 中研研報, No. 175031（昭 51）

(12) M. Ishii \& J. Hojo: "Statistics on Fine Structure of Cloud-to-Ground Lightning Field Waveforms", J. Geophys. Res., 94, 13267 (1989)

(13) C. D. Weidman, et al. : "The Fine Structure of Lightning Return Stroke Wave Forms", ibid., 83, 6239 (1978)

（14）園井, 他：「落雷位置標定システムによる冬季雷の捕捉につ いて」, 平元電気学会全大, 1192

(15) P. W. Peckham, et al. : "Lightning Phenomenology in the Tampa Bay Area", J. Geophys. Res., 89, 11789 (1984)

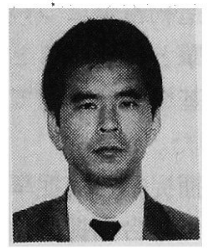
山田
勝 (正員)

昭和 31 年 12 月 29 日生。 52 年 3 月岐阜工業高等専門学校電気工学科 卒業。同年 4 月関西電力 (株) 入社。 現在, 同社総合技術研究所勤務。主 として, 雷および送電に関する研究に従事。

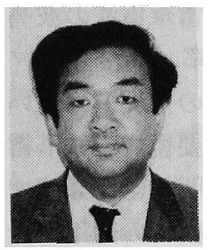

永 井 敏 雄 (正員)

昭和 30 年 2 月 27 日生。 50 年 3 月石川工業高等専門学校電気工学科 卒業。同年 4 月関西電力 (株) 入社。 現在, 闰社総合技術研究所勤務。主 として, 雷および送電に関する研究に従事。電子情報 通信学会会員。

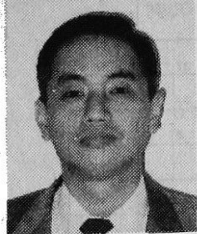

園 \#康夫 (正員)

昭和 27 年 12 月 5 日生。 52 年 3 月京都大学大学院工学系研究科修士 課程修了。同年 4 月関西電力 (株) 入 社。現在, 同社総合技術研究所勤 務。主として，雷扔よび送電に関する研究に従事。

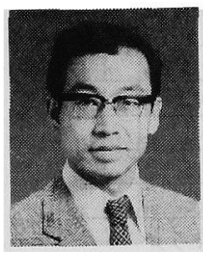

\section{石 井 勝 (正員)}

昭和 24 年 3 月 11 日生。 51 年 3 月東京大学大学院工学系研究科博士 課程修了。同年 4 月同大学助教授, 生 産技術研究所勤務, 現在に至る。工 学博士。主として, 系統絶緑, 自然雷, 高電圧現象の 測定に関する研究に従事。平成元， 2 年度電気学会東 京支部評議員。IEEE Senior Member。

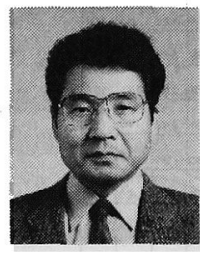

北 條 準 一 (正員)

昭和 15 年 2 月 10 日生。 37 年 3 月千葉工業大学電気工学科卒業。同 年 4 月東京大学生産技術研究所勤 務, 現在に至る。主として, 雷およ び高電圧工学に関する研究に従事。日本大気電気学会 会員。 